\title{
The use of a combination of tamoxifen and doxorubicin synergistically to induce cell cycle arrest in BT483 cells by down-regulating CDK1, CDK2 and cyclin D expression
}

\author{
Pei-Yun Chuang ${ }^{1}$, Cheng Huang ${ }^{2}$ and Hsiu-Chen Huang ${ }^{1 *}$ \\ *Correspondence: jane@mail.nhcue.edu.tw \\ 'Department of Applied Science, National Hsinchu University of Education, Hsinchu 30014, Taiwan. \\ ${ }^{2}$ National Research Institute of Chinese Medicine, Taipei 11221, Taiwan.
}

\begin{abstract}
Background: Tamoxifen and Doxorubicin are used alone or in combination to treat breast cancer. Although these drugs have been utilized in combination, the advantage of their combination, in terms of therapeutic efficacy, still remains controversial.

Methods: Cells were treated with Tamoxifen alone and doxorubicin alone or treated with both Tamoxifen and doxorubicin, cell cycle distribution, cell cycle regulatory protein, mRNA, and activity were measured.

Results: This study uses breast cancer cell lines to demonstrate the synergistic interaction between Doxorubicin and Tamoxifen, and to explain the CDK1 and CDK2 expression underlying the synergy. This study demonstrates that the combination of Doxorubicin and Tamoxifen significantly reduces the growth of ER-positive breast cancer cells and that this is driven primarily by the enhanced effect of the decreased protein expression of the CDK1, CDK2 and cyclin D. It is also proposed that selective modification of AKT inactivation, ERK activation probably contributes to the synergistic interaction. Conclusions: Overall, the findings suggest that a combination of Doxorubicin and Tamoxifen could be effective in the treatment of ER-positive breast cancers, so this combination warrants further investigation.
\end{abstract}

Keywords: Tamoxifen, doxorubicin, BT483 cells, CDK1, CDK2

\section{Background}

Doxorubicin (Dox) and Tamoxifen (Tam) are both very effective in the treatment of breast cancer. Dox is one of the most effective agents available for metastatic breast cancer. It is classified as an anticancer anthracycline antibiotic and is commonly used in the treatment of multiple cancers, including bladder cancer, breast cancer, ovarian cancer, lung cancer and gastric cancer [1-4]. However, several randomized clinical studies have included this drug in adjuvant regimens, possibly because of a fear of long-term cardiotoxicity [5]. Tam is a nonsteroidal selective estrogen receptor modulator that is widely used in the treatment of hormone-dependent breast cancers. In the clinical environment, Tam is the most commonly used endocrine therapy for women with breast cancers that express estrogen receptors and has enhanced patient survival [6]. However, five-year Tam use has become associated with a number of serious side effects. Therefore, alternative interventions are needed to replace or to supplement current regimens. There are grounds for the belief that multiple drugs may be more effective in the treatment of breast cancer than a single drug. In accordance with this concept, the ideal regimen would contain at least two potent drugs [7]. For example, preclinical studies provide evidence that the combination of gefitinib and Tam results in a strong synergistic effect $[8,9]$.

Deregulation of cell cycle regulation is a general ha-
Ilmark of tumor formation and progression. Cyclins, cyclin-dependent kinases (CDKs) and CDK inhibitors play a well-established role in cell cycle control and have been attracting considerable research attention in the past decade. CDK1 and CDK2 are both thought to play an important role in cell proliferation and are probably associated with tumor aggressiveness and a poor prognosis. Thus, the direct targeting of CDK1 and CDK2 may be a useful therapeutic approach for breast cancer patients. Recent studies have shown that combined CDK2 and CDK1 depletion induces cell cycle arrest in breast cancer cells $[10,11]$. This study seeks to investigate whether similar effects could be achieved by reducing CDK activity, through the combination of Dox and Tam treatment.

Tam is the drug of choice for the treatment of estrogenreceptor positive breast cancer. While Dox may be used after relapse in patients, after Tam treatment, these drugs have been used in combination, but the advantage of this combination, in terms of therapeutic efficacy, still remains questionable. This study uses breast cancer cell lines to demonstrate the synergistic interaction between Dox and Tam, and to explain the CDK1 and CDK2 expression underlying the synergy.

\section{Materials and Methods \\ Cell culture}

The human breast cancer cell lines used in this study were MDA-MB-231, and BT483. MDA-MB-231 and BT483

(c) 2013 Huang et al; licensee Herbert Publications Ltd. This is an Open Access article distributed under the terms of Creative Commons Attribution License (http://creativecommons.org/licenses/by/3.0). This permits unrestricted use, distribution, and reproduction in any medium, provided the original work is properly cited. 
were obtained from the American Type Culture Collection (ATCC, Manassas, VA, USA) and were cultured in DMEM supplemented with $10 \%$ fetal calf serum and $1 \%$ penicillinstreptomycin, and maintained at $37^{\circ} \mathrm{C}$ in $5 \% \mathrm{CO}_{2}$ humidified air. The 231.neo and 231.eB transfectants, which were kindly provided by Dr. Mien-Chie Hung (The University of Texas, M.D. Anderson Cancer Center, Houston, TX), were cultured as previously described [12].

\section{MTT assay}

The effect of Tam, Dox, or NU6102 on cell growth was examined by MTT assay. Briefly, cells were seeded at $2 \times 10^{4}$ cells/well in a 24-well flat-bottomed plate for $24 \mathrm{~h}$, treated with varying concentrations of Tam, Dox, or NU6102 and incubated for an additional $48 \mathrm{~h}$. After incubation, $20 \mu \mathrm{l}$ of MTT solution ( $5 \mathrm{mg} / \mathrm{ml}$, Sigma Chemical Co.) was added to each well and incubated for $1 \mathrm{~h}$ at $37^{\circ} \mathrm{C}$. The supernatant was aspirated and the MTT-formazan crystals formed were dissolved in $200 \mu \mathrm{l}$ of dimethyl sulfoxide (DMSO), and measure the absorbance at $550 \mathrm{~nm}$.

\section{Flow cytometry}

For the flow cytometric analysis, cells were seeded on 10 $\mathrm{mm}$ petri-dishes for various times. After incubation, the cells were trypsinized, washed with PBS, and fixed in 100\% ethanol. Then, $1 \mathrm{ml}$ of propidium iodide solution $(50 \mu \mathrm{g} / \mathrm{ml})$ was added and analyzed by FACScan cytometry (Becton Dickenson, San Jose, CA).

\section{Immunoblotting (IB, western blotting)}

Cells were harvested and homogenized by using the golden lysis buffer. Protein content was determined against a standardized control, using the Bio-Rad protein assay kit (Bio-Rad Laboratories). The protein inputs in the western blot analyses were normalized by loading equal amounts of total protein lysates into the SDS-PAGE gel. Transferred onto polyvinylidene difluoride membranes (PVDF), and then probed with a different primary antibody, followed by secondary antibody conjugated with horseradish peroxidase. Reactive bands were visualized with an enhanced chemiluminescence system (ECL, Amersham).

\section{Reverse transcription polymerase chain reaction (RT-PCR)}

The total RNA was isolated by using TRIzol reagent (Invitrogen), as recommended by the manufacturer's instructions. The total $2 \mu \mathrm{g}$ RNA was reverse-transcribed into CDNA, using Moloney murine leukemia virus (M-MLV) reverse transcriptase and oligo (dT) 18 primer, by incubating at $37^{\circ} \mathrm{C}$ for $90 \mathrm{~min}$. Amplification of the CDNA was performed by polymerase chain reaction (PCR) in a final volume of $50 \mu$ l containing $2 \mu$ l of RT product, dNTPs (each at 200 $\mu \mathrm{M}), 1 \times$ reaction buffer, a $1 \mu \mathrm{M}$ concentration of each primer (CDK1, forward 5'- GATTCTATCCCTCCTGGT-3', reverse 5'- TAGGCTTCCTGGTTTCC-3'; CDK2, for-ward
5'- CGCTTCATGGAGAACTTC-3', reverse 5'- ATGGCAGAAAGCTAGGCC - $3^{\prime}$; Cyclin D, forward 5'- CTG TTT GGC GTT TCCCAGA-3', reverse 5'-T CCT CCT CAC ACC TCC TC3'; GAPDH, forward 5'- TGAAGGTCGGTGTGAACGGATTTGGC-3', reverse 5'-CATGTAGGCCATGAGGTC CACCAC- $3^{\prime}$ ) and 50 units/ $\mathrm{ml}$ Pro Taq DNA polymerase. The amplification cycle were $95^{\circ} \mathrm{C}$ for $30 \mathrm{~s}, 55^{\circ} \mathrm{C}$ for $1 \mathrm{~min}$ and $72^{\circ} \mathrm{C}$ for $1 \mathrm{~min}$. The sample of each PCR product was separated by electrophorese on a $1.5 \%$ agarose gel after 35 cycles and visualized by ethidium bromide staining.

\section{Statistical analysis}

The results obtained are expressed as means \pm S.E. Each value is the mean of at least three separate experiments in each group. The significance of the difference ( $p$ value) was statistically analyzed by ANOVA, followed by Dunnett's multiple comparison test, to assess the statistical significance $\left({ }^{*} p<0.05\right)$.

\section{Results}

The combination of Dox and Tam suppressed cell growth and induced morphological changes in breast cancer cells

Combination index $(\mathrm{Cl})$ was calculated to asses synergistic effect $(\mathrm{Cl}<1)$, additive effect $(\mathrm{Cl}=1)$, or antagonistic effect $(\mathrm{Cl}>1)$. The $\mathrm{Cl}$ value of co-treatment with Dox and Tam was evaluated by using MTT assay in estrogen receptor (ER) -positive (BT483), estrogen receptor -negative (MDAMB-231) and Her2-overexpressing (231eb) breast cancer cells. Dox significantly inhibited the cell proliferation in BT483, MDA-MB-231, 231neo, and 231eB cells in a dosedependent manner with an IC50 value of $0.67 \mu \mathrm{M}, 0.91 \mu \mathrm{M}$, $1.52 \mu \mathrm{M}$, and $1.51 \mu \mathrm{M}$, respectively (Figure $1 \mathrm{~A}$ ). Similar results were also observed in four breast cancer cell lines treated with Tam. The IC50 value of Tam in four breast cancer cell lines were $6.8 \mu \mathrm{M}, 6.1 \mu \mathrm{M}, 9.5 \mu \mathrm{M}$, and $10.5 \mu \mathrm{M}$, respectively (Figure 1B). After $48 \mathrm{~h}$ of incubation with $0.5 \mu \mathrm{M}$ Dox alone, the number of viable cells in BT483 was $82.3 \%$ of the number in the control, whereas the number after incubation with $4 \mu \mathrm{M}$ Tam alone was $98.7 \%$. Combined treatment with $0.5 \mu \mathrm{M}$ Dox and $4 \mu \mathrm{M}$ Tam reduced this number to $21.6 \%$ (Figure 1C). The calculation of the $\mathrm{Cl}$ for Tam and Dox combinations consistently showed $\mathrm{Cl}$ values $<1$, indicating synergism (Table 1). Similar results were also observed in Her2-overexpressing breast cancer cells (231eb). However, co-treatment with Dox and Tam reduced cell proliferation in MDA-MB-231 and 231neo cells only slightly. These findings indicate that Dox and Tam have a synergistic effect on the inhibition of BT483 and 231eb cell growth. The BT483 and 231eb cell lines were selected for further analysis.

The morphological changes in BT483, 231eb and 231neo cells co-treated with different concentrations of Dox and Tam for $48 \mathrm{~h}$ are illustrated in (Figure 2). The control cells were tightly attached to the culture plate. However, after combined treatment with Dox $(0.5 \mu \mathrm{M})$ and Tam $(4 \mu \mathrm{M})$, 


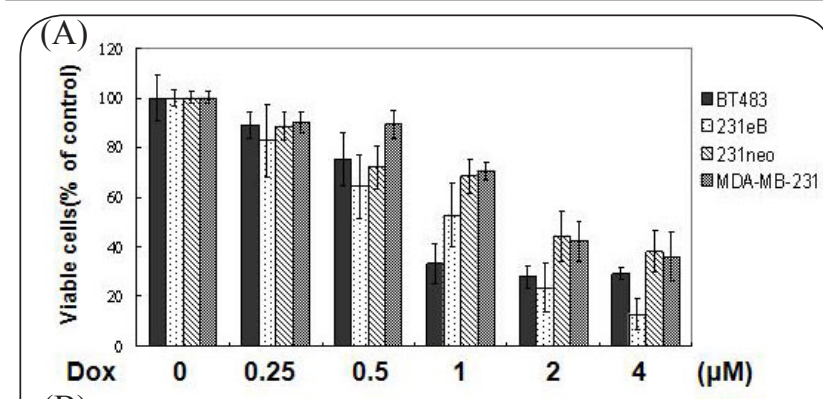

(B)

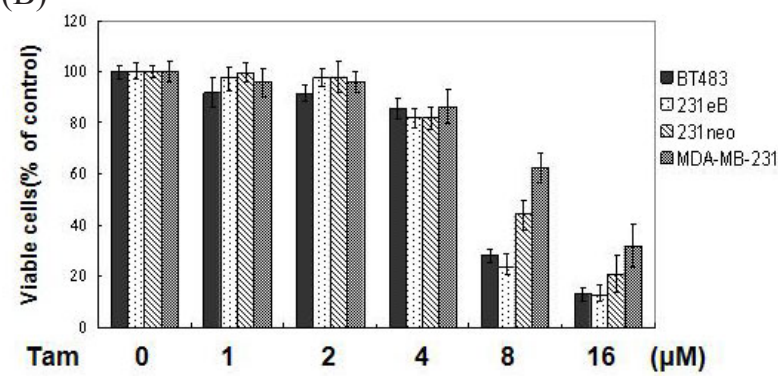

(C)

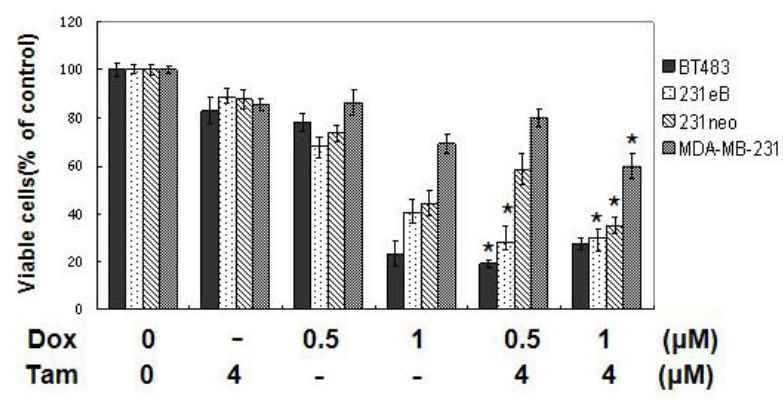

Figure 1. Effect of treatment with a combination of Tam and Dox on cell proliferation in breast cancer cells. BT483, MDA-MB-231, 231eB and 231neo cells were cultured in DMEM supplemented with $10 \%$ fetal calf serum for $24 \mathrm{~h}$. After culturing for 24-h, cells were treated with different concentrations of Dox and Tam for $48 \mathrm{~h}$. Cell growth inhibition was determined by MTT assay. The combination of Tam and Dox was more effective than either agent alone: ${ }^{\star} \mathrm{P}<0.05$.

the morphology of the BT483 cells changed dramatically, but not after treatment with either agent alone (Figure 2A). Similar results were obtained for 231eb cells (Figure 2B).

\section{Dox and Tam synergistically induced cell cycle arrest in BT483 cells}

The decreasing number of viable cells may be due to induction of cell cycle arrest or apoptosis. Thus, cell cycle distribution were performed on cells co-treated with Dox and Tam for $48 \mathrm{~h}$, using flow cytometry. In BT483 cells, Tam $(4 \mu \mathrm{M})$ alone marginally increased the cell population in the G1 phase by $6.8 \%$, as compared to the control, whereas Dox $(0.5 \mu \mathrm{M})$ alone drastically increased the cell population in the $\mathrm{G} 2$ phase by $35 \%$, as compared to the control. However, treatment with a combination of Dox (0.5 $\mu \mathrm{M})$ and Tam $(4 \mu \mathrm{M})$ synergistically increased the $G 2$ phase population by $18.0 \%$, as compared to treatment with Tam

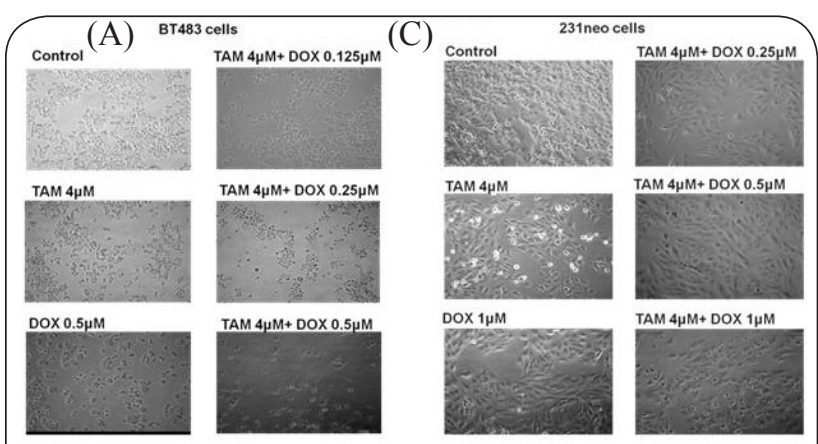

(B) $)_{231 \text { eB cells }}$

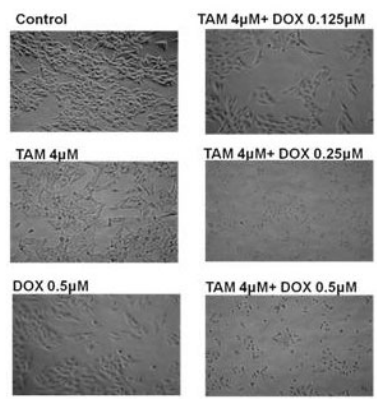

Figure 2. Effect of treatment with a combination of Tam and Dox on cell morphology in breast cancer cells. (A) BT483, (B)231eb, and (C) 231 neo cells were cultured in DMEM supplemented with $10 \%$ fetal calf serum for $24 \mathrm{~h}$. After culturing for 24 -h, cells were treated with different concentrations of Dox and Tam for 48h. Morphological changes in cells were examined by light microscopic observation.

Table 1. Combination index (CI) of co-treatment with Tamoxifen and Doxorubicin.

\begin{tabular}{lcc}
\hline Cell line & Combination & Combination index $(\mathrm{CI})$ \\
\hline \multirow{2}{*}{ BT483 } & $0.5 \mu \mathrm{M}$ Dox / $4 \mu \mathrm{M}$ Tam & 0.88 \\
& $1 \mu \mathrm{M}$ Dox / $4 \mu \mathrm{M}$ Tam & 1.25 \\
$231 \mathrm{eB}$ & $0.5 \mu \mathrm{M}$ Dox / $4 \mu \mathrm{M}$ Tam & 0.87 \\
& $1 \mu \mathrm{M}$ Dox / $4 \mu \mathrm{M}$ Tam & 1.12 \\
$231 \mathrm{neo}$ & $0.5 \mu \mathrm{M}$ Dox / $4 \mu \mathrm{M}$ Tam & 1.54 \\
& $1 \mu \mathrm{M}$ Dox / $4 \mu \mathrm{M}$ Tam & 0.71 \\
MDA-MB-231 & $0.5 \mu \mathrm{M}$ Dox / $4 \mu \mathrm{M}$ Tam & 3.01 \\
& $1 \mu \mathrm{M}$ Dox / $4 \mu \mathrm{M}$ Tam & 2.02
\end{tabular}

CI was defined as follows: $\mathrm{CI}=(\mathrm{D}) 1 /(\mathrm{Dx}) 1+(\mathrm{D}) 2 /$ (Dx) $2+$ (D)1(D)2/(Dx)1 (Dx)2(Dx) 1 and (Dx) 2 are the concentrations of drug 1 and drug 2 , which alone produce $\mathrm{x} \%$ effect. (D) 1 and (D) 2 are the concentrations of drug 1 combined with drug 2 to obtain the same response as drug 1 alone or drug 2 alone.

$(4 \mu \mathrm{M})$ alone, and increased the $\mathrm{G} 1$ phase population by $5.71 \%$, as compared to treatment with Dox $(0.5 \mu \mathrm{M})$ alone (Figure 3A). These results demonstrate that Dox and Tam act synergistically to arrest breast cancer cells in G1 and G2 phase. 
Chuang et al. Journal of Pharmaceutical Technology \& Drug Research 2013, http://www.hoajonline.com/journals/pdf/2050-120X-2-12.pdf

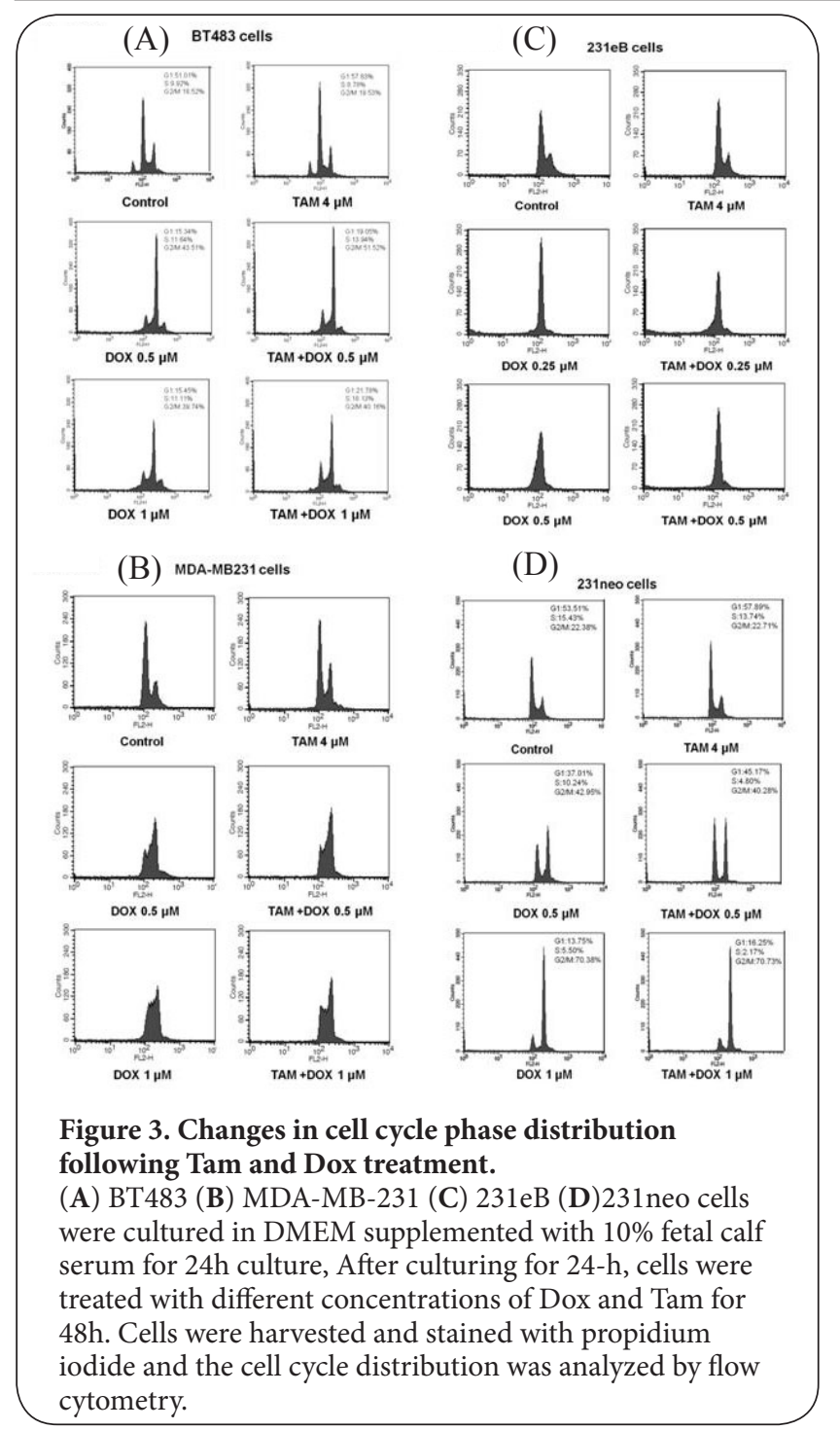

The combination of Dox and Tam modulated expression of cell cycle regulatory proteins in BT483 breast cancer cells

To identify the underlying molecular mechanism of the synergy between Dox and Tam, a western blotting analysis was used to profile the expression of cell cycle regulatory proteins in BT483 cells treated with a single agent and combination therapy. (Figure 4A and 4B) shows that Dox and Tam alone, or in combination, do not decrease cyclin $A$, cyclin B, cyclin E, cdc25, cullin 1, p21, or p27, erb2, $\beta$-Trcp protein level. However, co-treatment with Dox and Tam decreases CDK1, CDK2 and cyclin D in BT483 cells. The results show that the synergistic action of a combination of Dox and Tam on G1 and G2 phase cell cycle arrest in BT483 cells occurs because of their synergistic action on the down-regulation of CDK1, CDK2, and cyclin D. In order to identify the mechanism in the culture co-treated with Dox and Tam decrease the protein level of CDK1, CDK2 and cyclin D, the mRNA level of CDK1, CDK2 and cyclin D was first examined. As shown in (Figure 4C), no significant
(A)

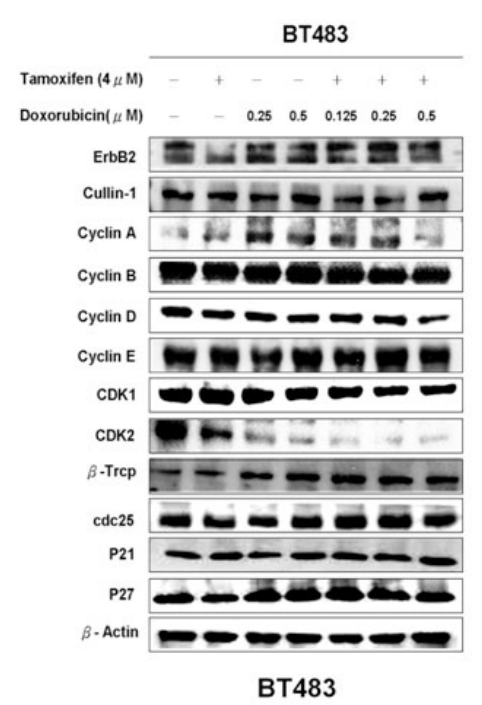

(B)

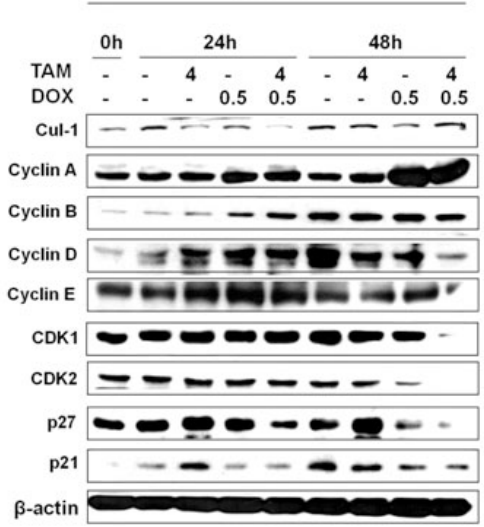

(C)

\section{BT483}

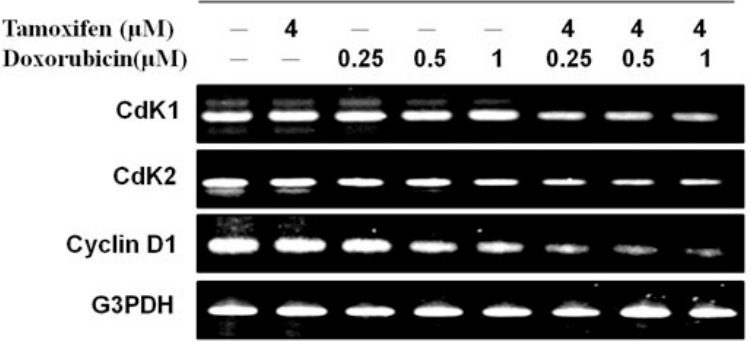

Figure 4. Effects of dose and treatment time for treatment with a combination of Tam and Dox on expression levels of cell cycle regulatory proteins in BT483 cells.

BT483 cells were treated with DMSO alone (CON), $4 \mu \mathrm{M}$ Tam, $4 \mu \mathrm{M}$ Tam plus varying concentrations of Dox, for $48 \mathrm{~h}(\mathrm{~A})$, or $4 \mu \mathrm{M}$ Tam plus $0.5 \mu \mathrm{M}$ Dox for the indicated times $(24 \mathrm{~h}, 48 \mathrm{~h})(\mathbf{B})$. Total cell lysates were prepared and western blot analysis was performed. $\beta$-Actin was used as an internal control, to ensure equivalent protein loading. (C) BT483 cells were treated with DMSO alone (CON), $4 \mu \mathrm{M}$ Tam, $4 \mu \mathrm{M}$ Tam, plus various concentrations of Dox for $48 \mathrm{~h}$. Total RNA was isolated and the mRNA expression was analyzed by reverse transcription-polymerase chain reaction (RT-PCR).

change in CDK1 and CDK2 levels is observed in the culture co-treated with Dox and Tam. These results indicate that 

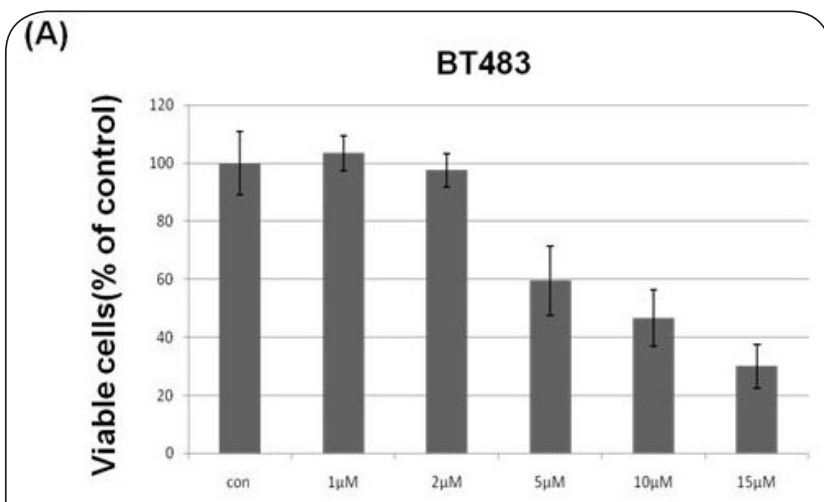

NU6102

(B)

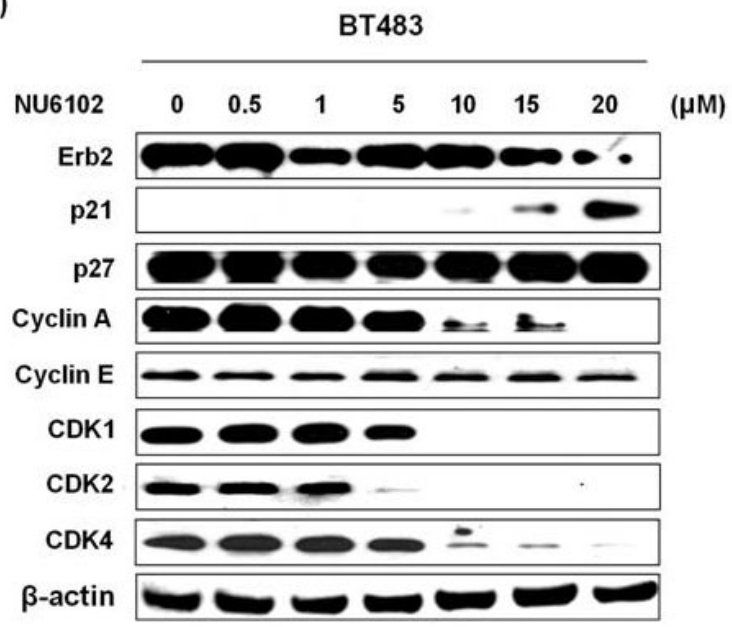

Figure 5. Effect of NU6102 on cell proliferation and protein expression in BT483 cells.

(A) The cells were cultured in DMEM supplemented with $10 \%$ fetal calf serum for $24 \mathrm{~h}$. After culturing for $24 \mathrm{~h}$, cells were treated with different concentrations of NU6102 for $48 \mathrm{~h}$. (B) BT483 cells were treated with different concentrations of NU6102, for 48h. Total cell lysates were prepared and western blot analysis was performed.

the decrease in CDK1 and CDK2 protein levels produced by treatment with Dox and Tam involves a posttranscriptional mechanism. In contrast, combined treatment with Dox and Tam synergistically decreases cyclin D mRNA expression in BT483. These results indicate that the decrease in cyclin D protein levels produced by cotreatment with Dox and Tam involves a transcriptional mechanism. Further experiments would be required to determine this possibility.

\section{Growth inhibition of BT483 by CDK1/2 inhibitor NU6102}

Combined treatment with Dox and Tam decreases CDK1 and CDK2 expression and causes cell cycle arrest in BT483 cells. This study investigates whether this can be mimicked using small-molecule CDK1/2 inhibitors, NU6102. In (Figure 5A), 5uM NU6102 decreased cell growth, cyclin A, CDK1 and CDK4 protein levels, but increased p21 and p27

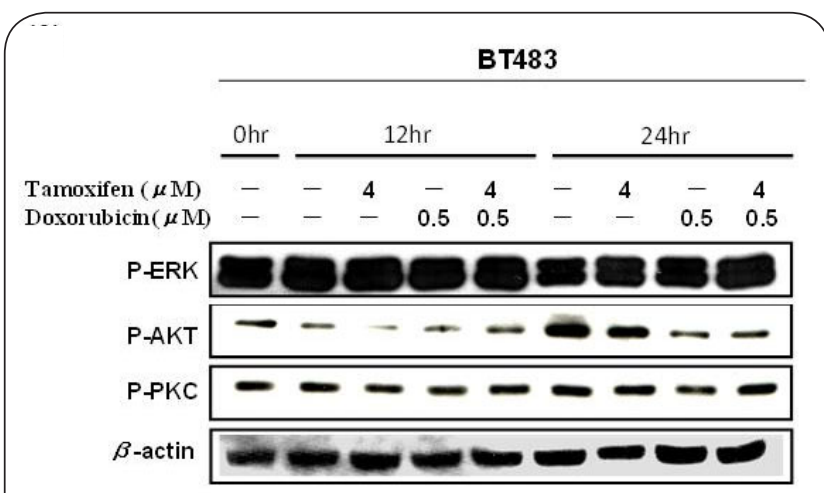

Figure 6. Effects of treatment time for treatment with a combination of Tam and Dox on expression levels of signal transduction proteins in BT483 cells.

BT483 cells were treated with DMSO alone (CON), $4 \mu \mathrm{M}$ Tam, $4 \mu \mathrm{M}$ Tam, plus various concentrations of Dox, for the indicated times. Total cell lysates were prepared, and western blot analysis was performed.

protein levels. Taken together, these results suggest that NU6102 decreases cell growth by repressing CDK2 protein expression in BT483 cells.

Combined treatment with Dox and Tam modulated the phosphorylation of intracellular signaling proteins AKT, ERK, MAPKs and PKC have been shown to be involved in CDK1, CDK2 and cyclin D regulation in various cell types [13-17]. In order to examine whether the activities of AKT, ERK, MAPKs and PKC are affected by combined treatment with Dox and Tam, the phosphorylation of Akt, ERK, MAPKs and PKC in BT483 cells was analyzed after combined treatment with Dox and Tam for $12 \mathrm{~h}$ and $24 \mathrm{~h}$. In (Figure 6), combined treatment with Dox and Tam synergistically increases ERK phosphorylation. $0.5 \mu \mathrm{m}$ Dox treatment inhibits the phosphorylation of Akt, but combined treatment with Dox and Tam does not produce any synergistic effect on AKT activity. These results suggest that ERK were activated and played important roles in BT483 cells co-treated with Dox and Tam.

\section{Discussion}

Several studies have already reported that a combination of adjuvant endocrine therapy and chemotherapy is better than either treatment alone. These two therapeutic approaches can be combined without a significant increase in toxicity. Additionally, because their mechanisms are presumed to be different, there is a potential for an additive or synergistic effect. Although combining adjuvant endocrine therapy, using Tam, and chemotherapy, using Dox, has previously been studied in various clinical settings, the mechanism has not been established. This study is the first report to show that combined treatment with Dox and Tam has an enhanced effect on their inhibition of proliferation through down-regulation of CDK1, CDK2 and cyclin D expression 
in BT483 cells. This increased efficacy might also allow a reduction of Tam or Dox dosage, to minimize the negative side effects.

Combinations of chemotherapy and Tam adjuvant have yielded conflicting results for overall survival. Most studies report a benefit for Tam in receptor positive patients $[9,18,19]$, while two trials found evidence of benefit in receptor negative patients $[\mathbf{2 0 , 2 1 ]}$. Some trials have also reported statistically insignificant beneficial effects for the addition of Tam to adjuvant chemotherapy $[22,23]$. Ahmann et al., reported that combined chemohormonal therapy with Tam, Dox and cyclophosphamide resulted in a higher objective response rate and a long median survival in patients with ER-positive tumors [24]. Similarly, another study found that the combination of radiotherapy, Dox and Tam seemed to improve both relapse-free and overall survival in ER-positive tumors [5]. The results of this study tend to support the findings of the two earlier with respect to the synergistic effect on cell survival in ER-positive breast cancers, but not in ER-negative breast cancers.

\section{Conclusions}

In summary, it has been demonstrated that the combination of Dox and Tam significantly reduces the growth of ERpositive breast cancer cells and that this is driven primarily by the enhanced effect of the decreased protein expression of CDK1, CDK2 and cyclin D. It is also proposed that selective modification of AKT inactivation and ERK activation probably contributes to the synergistic interaction. Overall, these findings suggest that a combination of Dox and Tam could be effective for the treatment of ER-positive breast cancers, so this combination warrants further investigation.

\section{Competing interets}

The authors declare that they have no competing interests.

Acknowledgement

This work was supported by grants from the National

Science Council, Taiwan. (NSC 100-2313-B-134-001-MY3).

Publication history

Received: 06-Dec-2012 Revised: 15-Jan-2013

Re-Revised: 15-Mar-2013 Accepted: 19-Mar-2013

Published: 26-Mar-2013

\section{References}

1. Thomadaki $\mathrm{H}$ and Scorilas A: Molecular profile of breast versus ovarian cancer cells in response to treatment with the anticancer drugs cisplatin, carboplatin, doxorubicin, etoposide and taxol. Biol Chem 2008, 389:1427-34. | Article I PubMed

2. Bronchud $M H$, Howell A, Crowther D, Hopwood P, Souza L and Dexter TM: The use of granulocyte colony-stimulating factor to increase the intensity of treatment with doxorubicin in patients with advanced breast and ovarian cancer. Br J Cancer 1989, 60:121-5. | Article | PubMed Abstract | PubMed Full Text

3. Huober J, Schoch O, Templeton A, Spirig C and Thurlimann B: Interstitial pneumonitis after treatment with bevacizumab and pegylated liposomal doxorubicin in a patient with metastatic breast cancer. Chemotherapy 2010, 56:69-70. | Article I PubMed
4. Ikeda M, Matsumoto K, Niibe Y, Satoh T, Fujita T, Iwamura M, Ishiyama $\mathrm{H}$, Kotani $\mathrm{S}$, Hayakawa $\mathrm{K}$ and Baba S: The radiotherapy with methotrexate, vinblastine, doxorubicin, and cisplatin treatment is an effective therapeutic option in patients with advanced or metastatic bladder cancer. J Radiat Res 2011, 52:674-9. | Article | PubMed

5. Blomqvist C, Tiusanen K, Elomaa I, Rissanen P, Hietanen T, Heinonen $E$ and Grohn P: The combination of radiotherapy, adjuvant chemotherapy (cyclophosphamide-doxorubicin-ftorafur) and tamoxifen in stage II breast cancer. Long-term follow-up results of a randomised trial. Br J Cancer 1992, 66:1171-6. | Article | PubMed Abstract | PubMed Full Text

6. Cuzick J, Forbes JF and Howell A: Re: Tamoxifen for the prevention of breast cancer: current status of the National Surgical Adjuvant Breast and Bowel Project P-1 study. J Natl Cancer Inst 2006, 98:643; author reply 643-4. I Article I PubMed

7. Sheppard C, Beyel V, Fracchia J and Merlis S: Polypharmacy in psychiatry: a multi-state comparison of psychotropic drug combinations. Dis Nerv Syst 1974, 35:183-9. I PubMed

8. Wagner U, du Bois A, Pfisterer J, Huober J, Loibl S, Luck HJ, Sehouli J, Gropp M, Stahle A, Schmalfeldt B, Meier W and Jackisch C: Gefitinib in combination with tamoxifen in patients with ovarian cancer refractory or resistant to platinum-taxane based therapy--a phase II trial of the AGO Ovarian Cancer Study Group (AGO-OVAR 2.6). Gynecol Oncol 2007, 105:132-7. I Article | PubMed

9. Osborne CK, Neven P, Dirix LY, Mackey JR, Robert J, Underhill C, Schiff R, Gutierrez C, Migliaccio I, Anagnostou VK, Rimm DL, Magill P and Sellers M: Gefitinib or placebo in combination with tamoxifen in patients with hormone receptor-positive metastatic breast cancer: a randomized phase II study. Clin Cancer Res 2011, 17:1147-59. | Article | PubMed Abstract | PubMed Full Text

10. Park SS, Eom YW and Choi KS: Cdc2 and Cdk2 play critical roles in low dose doxorubicin-induced cell death through mitotic catastrophe but not in high dose doxorubicin-induced apoptosis. Biochem Biophys Res Commun 2005, 334:1014-21. | Article | PubMed

11. Johnson N, Bentley J, Wang LZ, Newell DR, Robson CN, Shapiro GI and Curtin NJ: Pre-clinical evaluation of cyclin-dependent kinase $\mathbf{2}$ and $\mathbf{1}$ inhibition in anti-estrogen-sensitive and resistant breast cancer cells. Br J Cancer 2010, 102:342-50. | Article I PubMed Abstract | PubMed Full Text

12. Yu D, Jing T, Liu B, Yao J, Tan M, McDonnell TJ and Hung MC: Overexpression of ErbB2 blocks Taxol-induced apoptosis by upregulation of p21Cip1, which inhibits p34Cdc2 kinase. Mol Cell 1998, 2:581-91. | Article | PubMed

13. Taylor JR, Lehmann BD, Chappell WH, Abrams SL, Steelman LS and McCubrey JA: Cooperative effects of Akt-1 and Raf-1 on the induction of cellular senescence in doxorubicin or tamoxifen treated breast cancer cells. Oncotarget 2011, 2:610-26. | Article | PubMed Abstract I PubMed Full Text

14. Shin JS, Woo SH, Lee HC, Hong SW, Yoo DH, Hong SI, Lee WJ, Lee MS, Jin YW, An S, Jin DH and Park IC: Low doses of ionizing radiation suppress doxorubicin-induced senescence-like phenotypes by activation of ERK1/2 and suppression of p38 kinase in MCF7 human breast cancer cells. Int J Oncol 2010, 36:1445-52. | Article | PubMed

15. Mingo-Sion AM, Marietta PM, Koller E, Wolf DM and Van Den Berg CL: Inhibition of JNK reduces G2/M transit independent of p53, leading to endoreduplication, decreased proliferation, and apoptosis in breast cancer cells. Oncogene 2004, 23:596-604. I Article I PubMed

16. Sang JL and Wang YC: [Effects of inhibition of PKC alpha on breast cancer cell phenotype and expressions of cyclin E and CDK2]. Shi Yan Sheng Wu Xue Bao 1999, 32:367-71. I PubMed

17. Liu DS, Krebs CE and Liu SJ: Proliferation of human breast cancer cells and anti-cancer action of doxorubicin and vinblastine are independent of PKC-alpha. J Cell Biochem 2007, 101:517-28. | Article | PubMed

18. Bianco AR, De Placido S, Gallo C, Pagliarulo C, Marinelli A, Petrella G, $D^{\prime}$ Istria $M$ and Delrio G: Adjuvant therapy with tamoxifen in operable breast cancer. 10 year results of the Naples (GUN) study. Lancet 1988, 2:1095-9. | Article | PubMed 
19. Fisher B, Redmond C, Brown A, Fisher ER, Wolmark N, Bowman D, Plotkin D, Wolter J, Bornstein R, Legault-Poisson S and et al.: Adjuvant chemotherapy with and without tamoxifen in the treatment of primary breast cancer: 5-year results from the National Surgical Adjuvant Breast and Bowel Project Trial. J Clin Oncol 1986, 4:459-71. | Article | PubMed

20. Tormey DC, Gray R, Gilchrist K, Grage T, Carbone PP, Wolter J, Woll JE and Cummings FJ: Adjuvant chemohormonal therapy with cyclophosphamide, methotrexate, 5-fluorouracil, and prednisone (CMFP) or CMFP plus tamoxifen compared with CMF for premenopausal breast cancer patients. An Eastern Cooperative Oncology Group trial. Cancer 1990, 65:200-6. | PubMed

21. Aydiner A, Ridvanogullari M, Anil D, Topuz E, Nurten R and Disci R: Combined effects of epirubicin and tamoxifen on the cell-cycle phases in estrogen-receptor-negative Ehrlich ascites tumor cells. J Cancer Res Clin Oncol 1997, 123:113-7. I Article I PubMed

22. Rutqvist LE, Cedermark B, Glas U, Johansson H, Rotstein S, Skoog L, Somell A, Theve T, Wilking N, Askergren J and et al.: Randomized trial of adjuvant tamoxifen combined with postoperative radiation therapy or adjuvant chemotherapy in postmenopausal breast cancer. Cancer 1990, 66:89-96. | PubMed

23. Senanayake F: Adjuvant hormonal chemotherapy in early breast cancer: early results from a controlled trial. Lancet 1984, 2:1148-9. | Article | PubMed

24. Ahmann FR, Jones SE, Moon TE, Hammond N, Miller TP and Durie BG: Chemohormonal therapy for advanced breast cancer with tamoxifen, adriamycin, and cyclophosphamide (TAC). Cancer 1985, 56:730-7. | Article | PubMed

\section{Citation:}

Chuang P-Y, Huang C and Huang H-C: The use of a combination of tamoxifen and doxorubicin synergistically to induce cell cycle arrest in BT483 cells by down-regulating CDK1, CDK2 and cyclin D expression. journal of Pharmaceutical Technology and Drug Research 2013, 2:12.

http://dx.doi.org/10.7243/2050-120X-2-12 